\title{
Lipoteikoik asitin ratlarda kronik bacak iskemisi üzerine etkisi
}

\author{
Özden Vezir'1, Barlas Naim Aytaçoğlu², Nehir Sucu ${ }^{3}$, Savaş Aktaş4, Lokman Ayaz \\ ${ }^{1}$ Mersin Şehir Hastanesi Kalp ve Damar Cerrahisi Kliniği, Mersin \\ 2 Girne Amerikan Üniversitesi Tip Fakültesi Kalp ve Damar Cerrahisi A.D., KKTC \\ ${ }^{3}$ Mersin Üniversitesi Tıp Fakültesi Kalp ve Damar Cerrahisi A.D., Mersin \\ ${ }^{4}$ Mersin Üniversitesi Tıp Fakültesi Histoloji ve Embriyoloji A.D., Mersin \\ 5 Trakya Üniversitesi Eczacılık Fakültesi Biyokimya A.D., Edirne
}

Öz

Amaç: Kronik arteryel iskemi tedavisinde cerrahi ve invazif girişimler yapılmaktayken bu yöntemlerin yetersiz kaldığı durumlarda tedavi seçeneklerinden biri terapötik anjiyogenezistir. Çalışmamızda, terapötik anjiyogeneziste yeni ve kontrollü bir süreç oluşturmak amacıyla, arka bacaklarında kronik arteryel iskemi oluşturulan ratlara, intramusküler lipoteikoik asit enjeksiyonu yapıldı ve anjiyogenezis süreci değerlendirildi. Yöntem: Gruplardaki rat sayısı istatistiksel yöntemle belirlenerekherbirinde onar rat bulunan toplam dört grup oluşturuldu. Kontrol grubuna herhangi bir işlem uygulanmadl, iskemi grubuna kronik iskemi modeli oluşturuldu, serum fizyolojik grubuna iskemi oluşturulduktan sonra serum fizyolojik enjeksiyonu yapıldı, lipoteikoik asit grubuna iskemi oluşturulmasını takiben intramusküler lipoteikoik asit enjeksiyonu yapıldı. Ratlar laboratuvar ortamında otuz gün boyunca vital bulgular ve enfeksiyon açısından takip edildikten sonra anestezi verilmesini takiben ekssanguinasyon yöntemiyle sakrifiye edildi, toraks ön duvarı açıldı, kalp içerisinden enjektör yardımıyla 5 cc kan alınarak biyokimyasal analizler yapıldı, toplanan kan örneklerinde proanjiyogenik faktörlerden vasküler endotel büyüme faktörü ve anjiopoietin-1, antianjiyogenik faktörlerden endostatin ve anjiostatinin serumdaki düzeyleri ölçüldü. Ratların arka bacaklarından gastroknemius kasları çıkarılarak histopatolojik analizler yapıldı, alınan kas dokusu örnekleri ışık ve elektron mikroskobisi ile değerlendirildi. Bulgular: Yapılan değerlendirmeler sonucunda, lipoteikoik asit grubunda diğer gruplara göre yeni oluşan kapillerite sayısı, anjiopoietin-1 düzeyi, endostatin ve anjiostatin bakımından anlamlı derecede artış tespit edildi $(\mathrm{p}<0.05)$. Sonuç: Bulgularımız, kronik iskemi modelinde lipoteikoik asitin anjiyogenezisi etkin bir biçimde sağladığını, aynı zamanda proanjiyogenik ve anti-anjiyogenik sitokinlerin her ikisinde birden artışa yol açarak anjiyogenezisin kontrollü bir süreçte geliştiğini telkin etmektedir.

Anahtar sözcükler: Anjiyogenezis, kronik iskemi, lipoteikoik asit

\section{Yazının geliş tarihi: $\quad 21.06 .2018 \quad$ Yazının kabul tarihi:16.08.2018}

Sorumlu Yazar: Özden Vezir,Mersin Şehir Hastanesi Kalp ve Damar Cerrahisi Kliniği, Adres: Korukent Mh. 96015 Sk. Mersin Entegre Sağlık Kampüsü 33240 Toroslar/Mersin

Tel: 0 (324) 22510 00/ 2408, E-posta: ovezir@hotmail.com

$\mathrm{Bu}$ çalışma, "Lipoteikoik asit' in Anjiyogenezis Oluşturmadaki Etkinliği ve Arteriyel İskemi Tedavisindeki Yeri" adı altında Dr.Özden Vezir'in uzmanlık tezi olarak kabul edilmiştir (Kabul tarihi: 23.02.2011). Bu tez BAP TF CTB (ÖV) 2010-3 TU kodlu proje olarak Mersin Üniversitesi Bilimsel Araştırma Projeleri Birimi tarafından desteklenmiştir. 


\title{
Effect of lipoteichoic acid on chronic limb ischemia in rats
}

\begin{abstract}
Aim: While surgical and invasive interventions are being performed in the treatment of chronic arterial ischemia, one of the treatment options when these methods are inadequate is therapeutic angiogenesis. In our study, intramuscular lipoteichoic acid injection was performed in rats with chronic arterial ischemia on their hind limbs, in order to establish a new and controlled process in therapeutic angiogenesis, and the angiogenesis process was evaluated. Methods: The number of rats in the groups was determined by statistical method, and four groups with ten rats in each group were formed. No action was taken on the control group, a model of chronic ischemia was formed in the sham group, in saline group, saline was injected after ischemia, injection of intramuscular lipoteichoic acid was performed in the lipoteichoic acid group following ischemia formation. Rats were sacrificed by exsanguination method following anesthesia after the rats were followed for 30 days in the laboratory for vital signs and infection, the thoracic anterior wall was opened, biochemical analyzes were performed by taking $5 \mathrm{cc}$ of blood from the heart through the injector, blood levels of proangiogenic factors, vascular endothelial growth factor and angiopoietin-1, anti-angiogenic factors, endostatin and angiostatin were measured in serum samples collected. Gastrocnemius muscles were removed from the hind limbs of the rats and histopathological analyzes were performed. The muscle tissue samples were evaluated by light and electron microscopy. Results: As a result of the evaluations made, there was a significant increase in the number of capillary vessels, angiopoietin-1 level, endostatin and angiostatin in the lipoteichoic acid group compared to the other groups $(\mathrm{p}<0.05)$. Conclusion: Our results suggest that lipoteichoic acid helps in the development of angiogenesis effectively and also provides a controlled angiogenesis by stimulating both the proangiogenic and antiangiogenic cytokines simultaneously.
\end{abstract}

Key words: Angiogenesis, chronical ischemia, lipoteichoic acid

\section{Giriş}

Bilindiği üzere kardiyovasküler hastalıklarda temel problem arteryel akımın yavaşlaması veya tamamen ortadan kalkmasıyla meydana gelen iskeminin hedef organ veya dokularda yarattığı hasarlanmadır.

Kronik arteryel iskeminin tedavisinde temel hedefler, semptomları azaltmak, yaşamı uzatmak, kas hasarını azaltmak ve tekrarını önlemektir. Bu amaçla genellikle anti-iskemik ilaçlar, antiplatelet ajanlar, antikoagülanlar, gerektiğinde perkütan girişim, stent uygulaması ve baypas cerrahisi ile gerçekleştirilir.1,2 Bu yöntemlerin yetersiz kaldığı durumlarda ise terapötik anjiyogenezis oluşturmak için yeni araştırmalar planlanmıștır.

\footnotetext{
Arteryel iskemide, mevcut kollateral damar yapısının arttırılması tedavi seçeneklerinden biridir.Bu amaçla yapılan araştırmalardan birisi"gen tedavisi" adı verilen yöntemdir.Bu tedavi protokolü,
}

vasküler endotelyal büyüme faktörü (VEGF) veya fibroblast büyüme faktörü (FGF) gibi proteinleri kodlayan genlerin avirülan virüslere (sitomegalovirüs) transfekte edildikten sonra iskemik hedef organa ulaştırılmasıyoluyla yapılmaktadır. ${ }^{3}$

Bunun dişında, kronik arteriyel iskemide anjiyogenezisi arttırmak amacıyla son yıllarda kök hücrelerle ilgili çalışmalar yapılmış, embriyonel ve periferik kök hücreler terapötik anjiyogenezis oluşturmada kullanılmıştır. ${ }^{4}$

Koroner arter hastalığı ve periferik arteryel hastalık gibi kronik iskemik hastalıklarda, karmaşık bir patofizyolojik mekanizma yoluyla iskemik dokuda anjiyogenezis meydana gelmektedir. Anjiyogenezis sürecinde proanjiyogenik ve anti-anjiyogenik sitokinlerin rol oynadığ bilinmektedir. ${ }^{5}$ İskemiye uğramış dokularda sitokinlerin artması ve makrofajların uyarılmasıyla anjiyogenezis süreci başlatılmaktadır.6,7 Ayrıca anjiyogenik uyaranların artışı ve anjiyogenez 
inhibitörlerinin azalışı anjiyogenezisin başlangıcında önemli rol oynamaktadır. ${ }^{8}$ VEGF ve anjiopoietin-1 (Ang-1) temel anjiyogenik faktörlerden, anjiostatin ve endostatin ise temel anti-anjiyogenik faktörlerdendir. ${ }^{9}$

VEGF, özellikle endotel hücreleri için özgül etkilere sahip olan multifonksiyonel bir büyüme faktörü ailesidir. ${ }^{10}$ VEGF, hem gelişim sırasında, hem de yetişkinde, vaskülogenez ve anjiyogenez için önemli ve gereklidir. ${ }^{11}$

Bir diğer temel anjiogenik faktör olan Ang-1, 70 kDa ağırlığında, glikoprotein yapıda bir moleküldür ve embriyo gelişim sürecinde damar yapısının oluşumunda kritik rol oynar. ${ }^{12 H a y v a n ~ c ̧ a l ı s ̧ m a l a r ı n d a ~ d a ~}$ anjiopoietinin vasküler yapıların matürasyonu için gerekli olduğu gözlenmiştir. ${ }^{13}$

Anti-anjiyogenetik faktörlerden endostatin, kollajen tip XVIII'in karboksi terminalinden elde edilir ve endotelyal hücrelerin çoğalmasını ve migrasyonunu önler. ${ }^{14}$ Yapılan çalışmalarda endostatinin anjiyogenezi baskıladığı gösterilmiştir. ${ }^{15-16}$

Bir diğer anti-anjiyogenik faktör olan anjiostatin, in vivo olarak, metastazların anjiyogenezise bağımlı büyümesi kadar deneysel primer tümör büyümesini de engeller.17 Başlangıç çalışmalarında elde edilen insan anjiostatini 40,42 ve $45 \mathrm{kDa}$ olarak üç moleküler ağırlık içerir ve her üç molekül de endotel hücre çoğalmasını benzer şekilde inhibe eder. ${ }^{18}$

$\begin{array}{lcr}\mathrm{Bu} & \text { bilgilerin ışığı } & \text { altında } \\ \text { anjiyogenezis } & \text { süreci } & \text { sirasıyla; } \\ \text { proanjiyogenik } & \text { faktörlerin } & \text { artması, }\end{array}$ proteolitik yıkılma ve endotel hücresi göçünden sonra yeni oluşan kapillerler, uygun anjiyogenez ortaya çıktıktan sonra anjiyogenik faktörlerde azalma ve anjiyogenez inhibitörlerinde artış şeklinde özetlenebilir, böylece endotel hücreleri sessiz bir hale bürünür ve damarlar kan akımını başlatmaya hazır hale gelmiş olur. ${ }^{19}$

Düzenli bir anjiyogenezis sürecinde proanjiogenik ve anti-anjiyogenik faktörlerin ikisine birden ihtiyaç olduğu kadar, anjiyogenezisin oluşması ve düzenlenmesi için Nitrik oksit de gereklidir. ${ }^{20}$ Lipoteikoik asit (LTA), vasküler düz kas hücrelerinden, indüklenebilir nitrik oksit sentaz salınımını arttırır.21,22

LTA, gram pozitif bakterilerin hücre duvarında, duvara sıkıca tutunmuş olan ve açil grubu içeren bir komponenttir. Bakterilerin hücreye yapıșmasını, kolonizasyonunu ve invazyonunu kolaylaştırma fonksiyonuna sahip bir adezyon molekülüdür. ${ }^{23}$

LTA ile ilgili yapılan çalışmalar incelendiğinde, LTA'nın hücresel aktivite ve sitokin sentezinin potent indükleyicisi olduğu, bununla beraber, yüksek seviyede saflaștırılmıș LTA'nın kanda sitokin cevabını indüklediği gösterilmiştir. ${ }^{24,25}$

Diğer yandan LTA, CD14 ile etkileşime girerek, inflamatuvar sitokin üretimine neden olan NF- $\mathrm{B}$ aktivasyonunu indüklerken IL-6 ve TNF- $\alpha$ gibi proanjiyogenik sitokinlerin makrofaj ve monositlerden salınmasina da neden olur. ${ }^{26,27}$

$\mathrm{Bu}$ çalışmadaki amacımız, ratların arka bacaklarında kronik iskemi oluşturulduktan sonra, iskemik kas dokusuna stafilococcus aureus'tan elde edilen lipoteikoik asit (LTA) enjeksiyonu yapılarak anjiyogenezis sürecini değerlendirmektir. Oluşturduğumuz kronik iskemi modelinde iskeminin anjiyogenezisi stimüle etmesine ek olarak, LTA'nın majör sitokin stimülanı olması nedeniyle, uygulandığı dokuda proanjiyogenik ve antianjiyogenik ajanların ikisini birden artıracağı ve bu nedenle kontrollü ve hızlı bir anjiyogenezis süreci yaratacağı düşünülmüştür.

\section{Yöntem}

$\mathrm{Bu}$ çalışmada hayvan hakları, Guide for the Care and Use of Laboratory Animals (http://www.nap.edu/catalog/5140.html) prensipleri doğrultusunda korunmuş ve Mersin Üniversitesi Hayvan Deneyleri Yerel Etik Kurulu (24.02.2010 tarih, 2010/23 sayı) onayı alınmıştır. 
Çalışma, ortalama 250g ağırlığında, toplam 40 adet erkek albino wistar rat üzerinde yapıldı. Rat sayısı istatistiksel güç analizi yapılarak hesaplandı. Her bir grupta 10'ar rat olacak şekilde dört farklı grup oluşturuldu. Kontrol grubuna hiç bir işlem uygulanmazken diğer gruplarda kronik iskemi modeli oluşturuldu. ${ }^{28}$ Kronik iskemi oluşturmak için ratlar anestezi(Ketamine $75 \mathrm{mg} / \mathrm{kg}$, Xylazine $10 \mathrm{mg} / \mathrm{kg} \quad$ i.p.) sonrasında, alt ekstremite uyluk iç yüzleri $\% 10$ povidon iyodin ile temizlenerek, sol ve sağ inguinal bölgelere yaklaşı $1 \mathrm{~cm}$ 'lik kesi yapıldı. ${ }^{29}$ Femoral arterler bulundu, her iki femoral arter, başlangıç seviyesinden trifukasyon seviyesine kadar 3/0 ipek sütür ile ligatüre edilerek çıkarıldı, kanama kontrolü yapıldıktan sonra cilt kesisi 5/0 polipropilen sütür kullanılarak kapatıldı.

\section{Kontrol grubu (KG):Bu gruptaki ratlar anestezi (Ketamine $75 \mathrm{mg} / \mathrm{kg}$,} Xylazine $10 \mathrm{mg} / \mathrm{kg}$ i.p.) verilip uyutulduktan sonra ekssanguinasyon yöntemiyle sakrifiye edildi. ${ }^{30}$ Biyokimyasal parametreler için kalp içerisinden5 ml kan alındl, her iki gastroknemius kasından histopatolojik incelemeler için doku örneği alındı, işlem sonrası ratlar hayvan laboratuvarı yetkilisi tarafından usulüne uygun olarak imha edildi.

İskemi grubu (IG):Bu gruptaki ratlar iskemi oluşturulduktan sonra 30 gün takip edildi, bu süre zarfında vital bulgular kontrol edildi.30 gün sonra ratların anestezisini (Ketamine $75 \mathrm{mg} / \mathrm{kg}$, Xylazine $10 \mathrm{mg} / \mathrm{kg}$ i.p.) takiben ekssanguinasyon yöntemiyle sakrifiye edildi, biyokimyasal parametreler için kalp içerisinden $5 \mathrm{ml}$ kan alındı, her iki gastroknemius kasından histopatolojik incelemeler için doku örneği alındı, işlem sonrası ratlar hayvan laboratuvarı yetkilisi tarafından usulüne uygun imha edildi.

$S F$ grubu (SFG):Bu gruptaki ratlara, iskemi oluşturulduktan 24 saat sonra, 1 mlsteril \%0.9 NaCl, aseptik koşullarda, ratların seçilen bölgesine (M.gastroknemius) dört noktadan (her enjeksiyonda $0.25 \mathrm{ml}$ olacak şekilde ayarlandı) enjekte edildi. Ratlar 30 gün takip edildi, bu süre zarfında vital bulgular kontrol edildi,30 gün sonra ratların anestezisini (Ketamine $75 \mathrm{mg} / \mathrm{kg}$, Xylazine $10 \mathrm{mg} / \mathrm{kg}$ i.p.) takiben ekssanguinasyon yöntemiyle sakrifiye edildi, biyokimyasal parametreler için kalp içerisinden $5 \mathrm{ml}$ kan alındı, her iki gastroknemius kasından histopatolojik incelemeler için doku örneği alındı, işlem sonrası ratlar hayvan laboratuvarı yetkilisi tarafından usulüne uygun imha edildi.

LTA grubu (LTAG):Bu gruptaki ratlar iskemi oluşturulduktan 24 saat sonra, Staphylococcus aureus' tan elde edilen LTA (liyofilize ampül olarak, Sigma Chemical St. Louis. MO), steril \%0.9 $\mathrm{NaCl}$ içinde dilüe edilerek, $1 \mathrm{mg} / \mathrm{kg}$ dozunda toplam $1 \mathrm{ml}$ olacak şekilde, aseptik koşullarda ratların seçilen bölgesine (M.gastroknemius), dört noktadan (her enjeksiyonda $0.25 \mathrm{ml}$ olacak şekilde ayarlandı) enjekte edildi. Ratlar 30 gün takip edildi, bu süre zarfında vital bulgular kontrol edildi, 30 gün sonra ratların anestezisini (Ketamine $75 \mathrm{mg} / \mathrm{kg}$, Xylazine $\quad 10 \mathrm{mg} / \mathrm{kg} \quad$ i.p.) takiben ekssanguinasyon yöntemiyle sakrifiye edildi, biyokimyasal parametreler için kalp içerisinden $5 \mathrm{ml}$ kan alınd, her iki gastroknemius kasından histopatolojik incelemeler için doku örneği alındı, işlem sonrası ratlar hayvan laboratuvarı yetkilisi tarafından usulüne uygun imha edildi.

\section{Işlk Mikroskobik Doku Takibi ve İmmunohistokimyasal Boyama Protokolü}

Dokular 24 saat \%10 tamponlanmış nötral formalinde fikse edildikten sonra akar suda yıkandı. Daha sonra artan derecede alkollerden (\%80, \%90 ve \%96) geçirilerek dehidrate edildi, ksilol ile șeffaflandırıldı ve parafine gömüldü. Parafin bloklardan $5 \mu \mathrm{m}$ kalınlığında kesitler adeziv poli-L-lizin kaplı lamlara alındı. Kesitler deparafinize edilip rehidrate edildikten sonra distile su ile yıkandı. Endojen peroksidaz aktivitesini yok etmek için metanolde \%3' lük hazırlanmış hidrojen peroksitte 10 dakika bekletildi. Nonspesifik antikor bağlanmasını yok etmek için oda isısında blok solüsyonu (Novocastra®, RE7104) ile 10 dakika inkübe edildi. Daha sonra kesitlerin üzerine \%5 sığır serum albümin solüsyonunu içeren PBS' de (Phosphate buffered saline) hazırlanmış 1/100 dilüsyondaki tavşan poliklonal IgG Von Willebrand Factor 
primer antikoru (Abcam $\AA$, ab-6994) damlatıldı ve $+4{ }^{\circ} C^{\prime}$ de bir gece bekletildi. Ertesi gün önce biotin ile bağlanmış sekonder antikor solüsyonunda (Sensi Tek®, ABF125) 10 dakika, ardından Streptavidin-peroksidaz solüsyonu (Novocastra ${ }^{\circledR}$, RE7102) ile 20 dakika inkübe edildi ve PBS ile yıkandı. Son aşama olarak peroksidaz substratı olan diaminobenzidin (DAB) damlatıldı ve boyanma yoğunluğu mikroskop altında kontrol edilerek bir dakika beklendi. Kesitler distile suda beş dakika yıkandıktan sonra hematoksilen ile zıt boyama yapıldı. Negatif kontrol için ayrılan kesitlere primer antikor içermeyen $\% 0.5$ PBS-BSA (Phosphate buffered saline-Bovine serum albumin) damlatıldı. İncelemeler, Olympus BX50 marka ışık mikroskobu ile yapıldı ve Nikon Coolpix 5000 dijital kamera ile resimleri çekildi. İmmunohistokimyasal değerlendirme için; tüm gruplarda her bir kesitte X400 büyütmede 10 farklı alanda, Von Willebrand Factor ile immun işaretlenmiş endotele sahip kapillerler sayıldı.

\section{Elektron Mikroskobik Doku Takip Protokolü}

Dokular, fosfatll tuz tamponu ile hazırlanmış \%2.5' luk gluteraldehit solüsyonu ile dört-altı saat tespit edildi. Fosfatlı tuz tamponu ile yıkanan dokular, daha sonra \%1' lik osmium tetraoksit ile bir saat süreyle $+4{ }^{\circ} \mathrm{C}$ ' de ikinci kez fikse edildi ve $\operatorname{artan}$ derecede alkollerden (\%50, \%60, $\% 70, \% 80, \% 90, \% 96$ ) geçirildi. Propilen oksit ile şeffaflandırıldıktan sonra araldite gömüldü. Bloklardan, Leica UCT ultramikrotom ile alınan 70nm' lik kesitler, uranil asetat ve kurşun sitrat ile kontrastlandı. Tüm incelemeler, JEOL JEM 1011 marka elektron mikroskobu ile yapıldı ve ITEM dijital görüntüleme programı ile fotoğraflandl.

\section{Biyokimyasal Parametreler ve Değerlendirme}

Ratlardan alınan $5 \mathrm{ml}$ kan tüp içerisine konuldu, 10.000 devir/dk' da beş dakika santrifüje edilerek toplanan serumda ELISA test yöntemiyle VEGF (RayBio® Rat
VEGF ELISA Kit, Norcross, USA), Ang-1 (ELISA Kit for Rat Angiopoietin-1, Uscn Life Science Inc. Wuhanve, USA), endostatin (ELISA Kit for Rat Endostatin, Uscn Life Science Inc. Wuhanve, USA), anjiostatin (ELISA Kit for Rat Angiostatin, Uscn Life Science Inc. Wuhanve, USA) değerleri hesaplandl.

\section{İstatistiksel analiz}

Tanımlayıcı istatistiklerde ortalama,standart sapma ve minimummaksimum değerleri verilmiştir. Grupları karşılaștırmak için Tek Yönlü Varyans Analizi (OneWay Analysis of Variance) uygulanmıştır. Post-Hoc test olarak ise Tukey HSD testi kullanılmıştır. Grafiklerde Box, Whisker ve Dots birarada verilmiştir. İstatistiksel olarak anlamlılık seviyesi $\alpha=0.05$ olarak alınmıștır. Veri analizleri "MedicalStatisticsand Analysis Consultancy, New York, NY (www.mestacon.info) firmasının Türkiye temsilcisi AEK Araştırma ve Eğitim LTD, Teknopark, Mersin tarafından yapılmıştır. Analizlerde MedCalc ve SPSS yazılımları kullanılmıștır.

\section{Bulgular}

Işık mikroskobi bulguları

Her bir rattan alınan örneklerde X40 büyütmede on farklı alanda kapillerler sayılmıştır (Fotoğraf 1). Kapiller damar sayımının analizine göre gruplar arası istatistiksel olarak anlamlı bir fark vardır $(p<0.0001)$ (Tablo 1). LTAG ile diğer tüm gruplar karşılaştırıldığında anlamlı bir fark olduğu tespit edilmiştir, KG-LTAG $(\mathrm{p}<0.0001)$, İG-LTAG $(\mathrm{p}=0.018)$ ve SFGLTAG $(\mathrm{p}=0.036)$.

\section{Elektron mikroskobi bulguları}

$K G$ : Normal morfolojik özelliklere sahip kas hücreleri izlendi. Hücrelerdeki organeller, myofibrillerin yapısı ve düzenlenişi normal görünümdeydi.

IG ve SFG:Her iki grubun bulguları benzerdi. Hücrelerdeki myofibrillerin düzenlenişinde bozulmalar, bazı 
myofibrillerde yer yer incelme ve harabiyet saptandı. Miyofibrillerde bazı bölgelerde Z bandlarında kayıp ve düzensizlikler gözlendi. Miyofibriller arasındaki mitokondriyonlarda şişme ve krista kayıpları gibi dejenerasyon bulguları görüldü (Fotoğraf2).

LTAG:Bu gruptaki bulgular kontrol grubundakilerle benzerlik göstermekteydi. Kas hücrelerindeki myofibrillerin düzenlenişi ve yapısı normal görünümdeydi. Pleomorfik görünümdeki mitokondriyonlar normal yapıdaydı (Fotoğraf3).

\section{Biyokimyasal ölçüm bulguları}

1. VEGF parametresine göre gruplar arası istatistiksel olarak anlamlı bir fark gözlenmemiștir ( $\mathrm{p}=0.676)$ (Tablo1).

2. Ang-1 (ng/ml) parametresine göre gruplar arası istatistiksel olarak anlamlı bir fark vardır ( $\mathrm{p}=0.001)$ (Tablo 1$)$. LTAG'da Ang-1 düzeyi sırasıyla KG ve İG'na göre anlamlı düzeyde yükselmiștir $(\mathrm{p}<0.0001, \mathrm{p}=0.005)$. İG'da ise Ang-1 düzeyi SFG'na göre anlamlı derecede yükselmiștir $(\mathrm{p}=0.041)$.

3. Endostatin $(\mathrm{ng} / \mathrm{ml})$ parametresine göre gruplar arası istatistiksel olarak anlamlı bir fark vardır ( $\mathrm{p}=0.001)$ (Tablo 1$)$. LTAG'da endostatin düzeyi sırasiyla $K G$ ve İG'na göre anlaml düzeyde yükselmiştir $(p=0.001, \quad p=0.046)$. SFG'da endostatin düzeyi KG'na göre anlamlı düzeyde yükselmiştir ( $p=0.033)$.

\section{Anjiyostatin (pg/ml)} parametresine göre gruplar arası istatistiksel olarak anlamlı bir fark vardır $(\mathrm{p}=0.002)$ (Tablo 1). LTAG'da anjiyostatin düzeyi sırasıyla KG ve İG'na göre anlamlı düzeyde yükselmiştir ( $p=0.001, p=0.024)$.
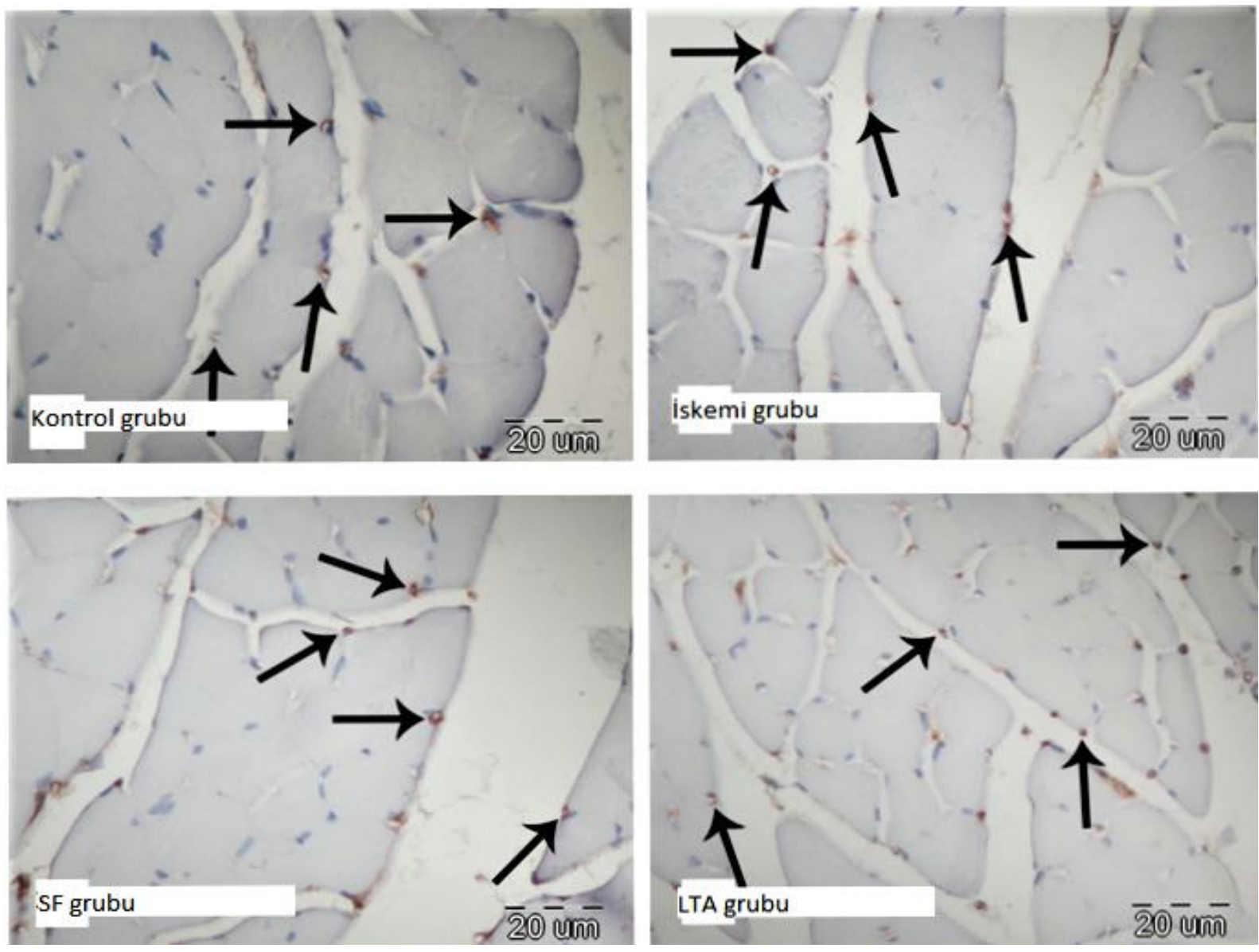

Fotoğraf 1. Işık mikroskobu incelemede yeni oluşan kapiller damarlar. Von Willebrand Faktor ile immun işaretlenmiş endotele sahip kapillerler (oklar, indirekt immunoperoksidaz X1200) 

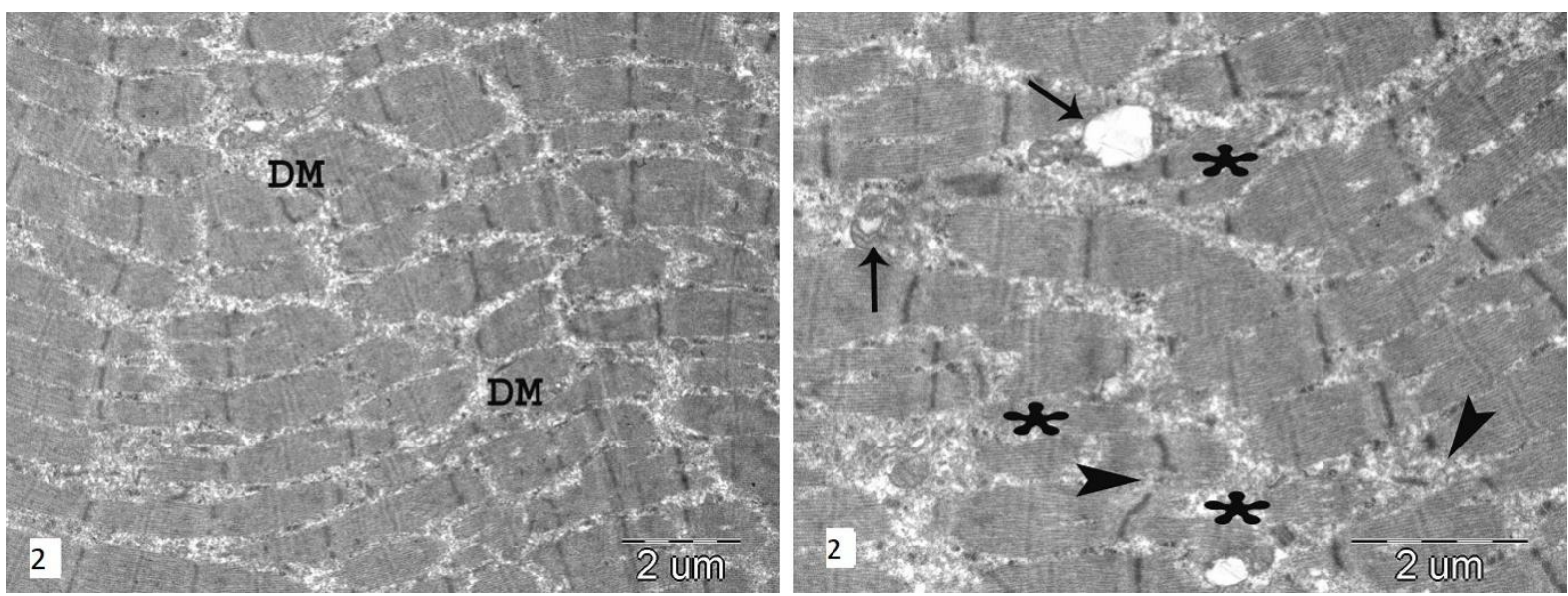

Fotoğraf 2. İskemi grubunda alınan kas örneklerinin elektron mikroskobi görüntüleri. Yer yer dejenere olmuş miyofibriller (DM) (X10000); dejenere mitokondriyonlar (oklar), yer yer incelmiş ve hasarlanmış miyofibriller (asteriskler), $\mathrm{Z}$ bandlarında kopma ve düzensiklik (ok başları)(X15000)
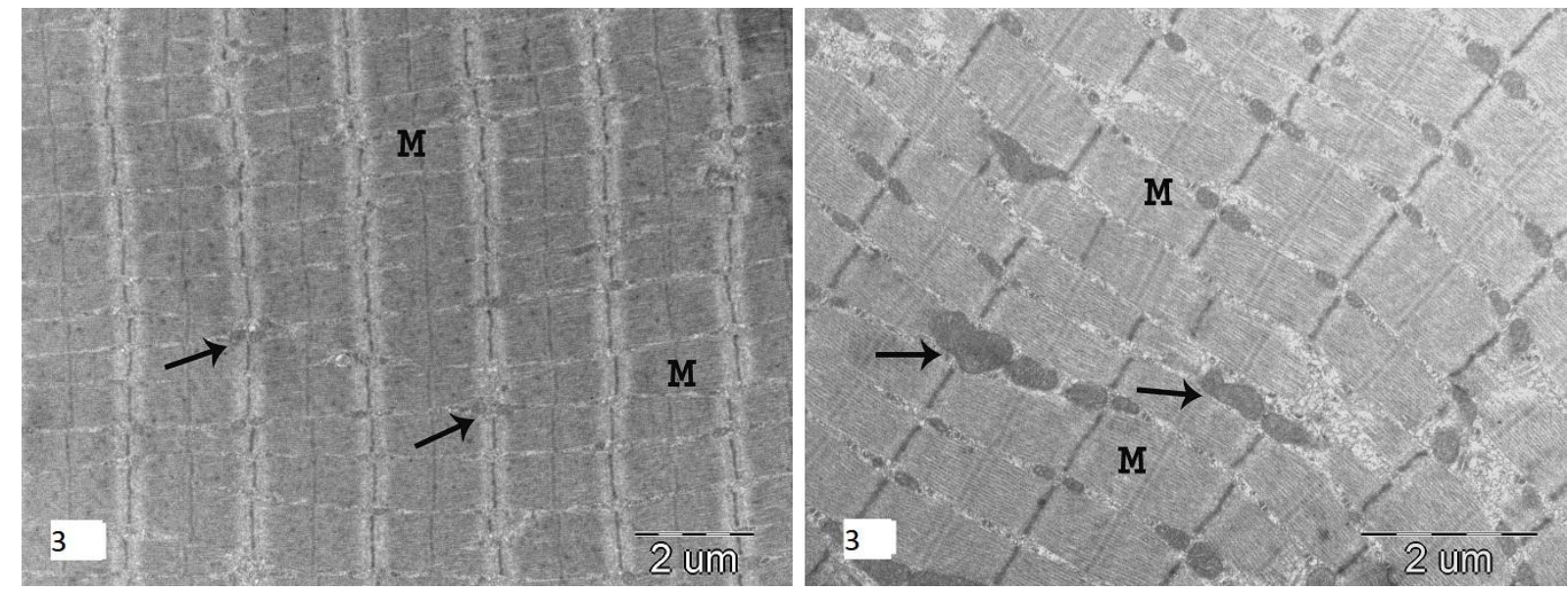

Fotoğraf 3. LTA grubundan alınan kas dokusu örneklerinin elektron mikroskobisi görüntüleri. Normal yapıda miyofibriller (M) ve mitokondriyonlar (oklar)(X10000, X15000)

Tablo 1. Grupların karșılaștırılması

\begin{tabular}{lccccc}
\hline & KG (Mean \pm SD $)$ & İG (Mean \pm SD $)$ & $\begin{array}{c}\text { SFG } \\
(\text { Mean } \pm S D)\end{array}$ & $\begin{array}{c}\text { LTAG } \\
(\text { Mean } \pm S D)\end{array}$ & p \\
\hline Ang-1 ng/ml & $14.998 \pm 2.3527$ & $16.035 \pm 2.3688$ & $17.096 \pm 3.1865$ & $20.588 \pm 3.2164$ & 0.001 \\
Anjiyostatin pg/ml & $1.081 \pm 0.1504$ & $1.163 \pm 0.1476$ & $1.202 \pm 0.2079$ & $1.378 \pm 0.1213$ & 0.002 \\
Endostatin ng/ml & $41.192 \pm 6.4785$ & $43.871 \pm 4.1958$ & $46.968 \pm 2.5472$ & $49.358 \pm 3.8199$ & 0.001 \\
VEGF pg/ml & $24.086 \pm 12.8763$ & $25.444 \pm 13.1479$ & $25.942 \pm 8.4711$ & $29.815 \pm 7.7874$ & 0.676 \\
Yeni Kapiller Sayıs & $9.1 \pm 1.4384$ & $13.41 \pm 5.9999$ & $13.94 \pm 3.9814$ & $19.16 \pm 3.7164$ & $<0.0001$ \\
\hline
\end{tabular}




\section{Tartışma}

$\mathrm{Bu}$ çalışmanın sonucunda LTA'nın, kronik bacak iskemisi olușturulan ratlarda, yeni oluşan kapiller sayısını diğer gruplar ile karşılaştırıldığında anlamlı derecede arttırarak anjiyogenezisi desteklediği gözlenmiştir. Işık mikroskobu altında yeni oluşan kapiller damar sayısının değerlendirilmesinde LTA grubu dışındaki grupların arasında fark saptanmamıştır.

Dokuların elektron mikroskobisi incelemesinde, iskemi ve SF grubunda iskemiye bağlı değişiklikler gözlenirken, LTA grubunda iskemik değişikliklerin görülmemesi LTA'nın terapötik anjiyogenezis üzerine olumlu etkisini desteklemektedir. Literatür incelendiğinde LTA ve terapötik anjiyogenezis ile ilgili bir çalışmaya rastlanmamıștır.

LTA grubunda Ang-1'in yükselmesi anjiyogenezis sürecini destekleyen bir bulgudur. Kim ve ark. ${ }^{31}$ yaptıkları araştırmada Ang-1 ile, granülosit koloni stimüle edici faktör tarafından mobilize edilen periferik kökenli kök hücrelerin vaskülojenik potansiyelinin arttığı, Shyu ve ark. ${ }^{32}$ yaptıkları çalışmada ise, sadece Ang1'i kodlayan plazmid DNA' sinın direkt intramusküler enjeksiyonunun tavşanların iskemik bacaklarında revaskülarizasyonu arttırdığ 1 gösterilmiştir. Benzer şekilde bizim çalışmamızda da, LTA grubundaki yeni oluşan kapiller sayısındaki anlamlı artışla paralellik gösteren Ang-1 düzeylerinin yüksekliği, LTA' nın iskemik dokuda anjiyogenezisi arttırdığını desteklemektedir. Nykänen ve ark.33, yaptıkları deneysel çalışmada, kardiyak allogreft arteriyosklerozunda Ang- $1^{\prime}$ in koruyucu etkisinin olduğunu ve arteriyel endoteli stabilize ettiğini göstermişlerdir. LTA grubunda Ang-1' in hedeflenen düzeyde anlamlı derecede artış göstermesiyle sadece anjiyogenez üzerine olumlu etkilerinden değil, aynı zamanda yeni oluşan kapiller endotelini stabilize edici özelliğinden de yararlanılabilir.

Çalışmamızda, endostatin bakımından görülen farklılığın LTA ile kontrol grupları $(p=0.001)$, LTA ile iskemi grupları $(\mathrm{p}=0.046)$ ve SF ile kontrol grupları $(p=0.033)$ arasında olduğu, diğer grupların birbirine benzer olduğu gözlenmiştir. $\mathrm{Bu}$ analizde, iskemi ve SF gruplarında endostatin düzeyleri arasında fark saptanamamışken ( $p>0.05)$, LTA ve SF grupları arasında da fark bulunamamıștır ( $p>0.05)$ Gruplardaki endostatin düzeylerinin ortalamasına bakıldığında; $\mathrm{KG}=41.1 \mathrm{pg} / \mathrm{dl}, \quad \dot{\mathrm{I}} \mathrm{G}=43.8 \mathrm{pg} / \mathrm{dl}, \quad \mathrm{SFG}=46.9$ $\mathrm{pg} / \mathrm{dl}, \mathrm{LTAG}=49.3 \mathrm{pg} / \mathrm{dl}$ olarak ölçülmüştür. İskemi oluşturulduktan sonra endostatin düzeyindeki artış küçükten büyüğe doğru siralanacak olursa, $\quad \mathrm{KG}<\mathrm{I} G<\mathrm{SFG}<\mathrm{LTAG}$ şeklinde bir sonuç ortaya çıkmaktadır. LTA grubunda SF grubuna oranla daha fazla artış olmasına rağmen aradaki fark anlaml değildir, bu durumda LTA ve SF'in endostatin düzeyine aynı şekilde etki ettiği düşünülebilir. Bu durum, ratlara verilen LTA dozu ile ilişkili olabilir. Ayrıca, LTA'nın sadece SF'le karşılaştırıldığı farklı doz ve zaman aralıklarında yeni bir araştırmaya ihtiyaç vardır.

Diğer yandan, gruplar karşılaştırıldığında, antianjiyogenik bir faktör olan anjiyostatinin, LTA verilen grupta; kontrol ve iskemi gruplarına göre sirasiyla \%27.48 $(\mathrm{p}=0.001)$ ve $\% 18.42$ $(p=0.024)$ oranında arttığını saptadık. Literatür araştırıldığında anjiyogenezis sürecinde anjiyostatin artışının ne zaman gerçekleştiği konusunda bir bilgiye rastlanmamıștır. İskemi ve SF gruplarındaki artışın kontrol grubuna göre anlamlı fark yaratmaması; ratlarda oluşturulan iskemiden sonraki bir aylık sürede, anjiyogenezis oluşum sürecinin LTA verilen gruba göre daha yavaş seyrettiği ve buna bağlı olarak, antianjiyogenik faktörlerin artış sırasının henüz gelmediği şeklinde yorumlanabilir. LTA grubunda iskemi grubuna göre yüksek anjiyostatin ve endostatin değerleri kontrollü anjiyogenezis oluşumuna katkıda bulunabilir. Sadece proanjiyogenik faktörlerin uyarılması veya hedef organa ulaştırılması yoluyla hedeflenen terapotik anjiyogenezis sürecinde, yeni kapiller oluşumunun belirli bir aşamada durdurulması işlemi, organizmanın antianjiyogenik sistemlerinin kapasitesine bırakılmaktadır. Düzensiz bir süreçte meydana gelen anjiyogenezis ise neoplastik olmayan endometriyozis, 
romatoid artrit, psöriazis, hemanjiom gibi hastalıklarda söz konusudur. ${ }^{34-36} \mathrm{Bu}$ örneklerde olduğu gibi, proanjiyogenik ve antianjiyogenik sitokinler arasındaki dengenin bozulması nedeniyle ortaya çıan kontrolsüz anjiyogenezis istenmeyen sonuçlar ortaya çıkarabilir. LTA ise potent sitokin stimülanı olması nedeniyle hem proanjiyogenik hem de antianjiyogenik faktörleri arttırarak anjiyogenezis sürecinin daha kontrollü işlemesini sağlayabilir.

Çalışmamızda VEGF; LTA grubunda; kontrol, iskemi ve SF grubuna göre daha fazla artış göstermiş olmasına rağmen bu artıș istatistiksel olarak anlamlı bulunmamıștır ( $p>0.05)$. VEGF'deki artışın anlamlı derecede olmaması, verilen LTA dozuyla ilişkili olabilir. G. Merino ve ark. ${ }^{37} \mathrm{LTA}^{\prime}$ nın üveit yaptığını göstermek için yaptıkları deneysel çalışmada, sırasıyla, $3.75,7.5,15$ ve $30 \mathrm{mg} / \mathrm{kg}$ dozunda LTA kullanmışlardır. Literatürde, LTA' nın anjiyogenezis üzerine etkisinin araştırıldı̆̆ herhangi bir araştırma örneği olmadığından, bu çalışmada bir mililitre volüm içerisinde $1 \mathrm{mg} / \mathrm{kg}$ LTA olacak şekilde doz ayarlaması yapılmıştır. Çalışmamızda serum VEGF ve diğer parametrelerin serum değerlerinin ölçümü, kronik iskemi modeli oluşturulduktan sonra 30 günde yapılmıştır. Serum VEGF değerleri 30. günden önce pik değere ulaşmış ve sonrasında düşüşe geçmiş olabilir. VEGF, Ang-1, endostatin ve anjiyostatin ölçümlerinin sadece 30. günde yapılmış olması çalışmamızın kısıtlılığını oluşturmaktadır. Farklı zamanlarda, farklı dozlarla ölçüm yapılması gereken yeni çalışmalar tasarlanabilir.

Elde ettiğimiz sonuçlar, iskemik dokuda zaten artmış olan proanjiyogenik faktörlerin LTA etkisiyle daha çok arttığını desteklerken, antianjiyogenik faktörlerin artışına rağmen dengenin proanjiyogenik faktörlere doğru kaymasının sonucu olarak anjiyogenezis sürecinin antianjiyogenik sistemlerce belki de daha geç dengelenmesi sonucunda yeni kan damarlarının sayısı kontrol, iskemi ve SF gruplarına göre daha yüksek oranda gerçekleşmiştir.

Tüm bu bulgular ve değerlendirmelerin ışığı altında, LTA' nın arteriyel iskemi tedavisinde kullanılabilecek yeni bir ajan olabileceğinden, yapılacak daha ayrıntılı çalışmalarla sonuçlarımızın desteklenmesi gerekmektedir.

\section{Kaynaklar}

1. Norgren L, Hiatt WR, Dormandy JA, Nehler MR, Harris KA, Fowkes FGR. Intersociety consensus for the management of peripheral arterial disease (TASC II). Eur J Vasc Endovasc Surg2007;33(1):1-75.

2. Hennekens $\mathrm{CH}$. Increasing burden of cardiovascular disease current knowledge and future directions for research on risc factors. Circulation1998;97:1095-1102.

3. Sanada F, Taniyama Y, Muratsu J, Otsu R, Shimizu H, Rakugi H, Morishita R. Genetherapeutic strategies targeting angiogenesis in peripheral artery disease.Medicines 2018;5(2):31.

4. Durdu S, Akar A, Arat M, Eren NT, Özyurda Ü. Autologous bone-marrow mononuclear cell implantation for patients with Rutherford grade II-III thromboangiitis obliterans. J Vasc Surg 2006;44(4):732-739.

5. Distler JW, Hirth A, Kurowska M, Gay RE, Gay S, Distler O. Angiogenic and angiostatic factors in the molecular control of angiogenesis. Q J Nuclear Med 2003;47:149161.

6. Sasaki K, Murohara T, Ikeda H, Sugaya T, Shimada T, Shintani S, Imaizumi T. Evidence for the importance of angiotensin II type 1 receptor in ischemia-induced angiogenesis. $J$ Clin Invest2002;109:603-611.

7. Sunderkotter C, Steinbrink K, Goebeler M, Bhardwaj R, Sorg C. Macrophages and angiogenesis. J Leukoc Biol1994;55:410-422.

8. Shaker M. Angiogenesis and myogenesis. In: Kipshidze N, Fareed J, Moses JW, Serruys PW Eds.: Textbook of Interventional Cardiovascular Pharmacology, 1st Ed., London: Informa Healthcare, 2007:393-407.

9. Distler O, Neidhart M, Gay RE, Gay S. The molecular control of angiogenesis. Int Rev Immunol 2002;21:33-49. 
10. Yancopoulos GD, Davis S, Gale NW, Rudge JS, Wiegand SJ, Holash J. Vascularspecific growth factors and blood vessel formation. Nature 2000;407:242-248.

11. Bikfalvi A. Recent developments in the inhibition of angiogenesis: examples from studies on platelet factor-4 and the VEGF/VEGFR system. Biochem Pharmacol 2004;68:1017-1022.

12. Thurston G, Rudge JS, Ioffe E, Zhou H, Ross L, SD, Glazer N, Holash J, McDonald DM, Yancopoulos GD. Angiopoietin-1 protects the adult vasculature against plasma leakage. Nat Med 2000;6:460.

13. Thurston G. Role of Angiopoietins and Tie receptor tyrosine kinases in angiogenesis and lymphangiogenesis. Cell Tissue Res 2003;314:61-68.

14. O'Reilly MS, Boehm T, Shing Y, Fukai N, Vasios G, Lane WS, Flynn E, Birkhead JR, Olsen BR, Folkman J. Endostatin: an endogenous inhibitor of angiogenesis and tumor growth. Cell 1997;88:277-285.

15. Bix G, Iozzo V. Matrix revoluations: 'Tails' of basement-membrane components with angiostatic functions. Trends in Cell Biol 2005;15:52-59.

16. Abdollahi A, Hahnfeld P, Maercker C, Gröne HJ, Debus J, Ansorge W, Folkman J, Hlatky L, Huber PE. Endostatin's antiangiogenic signaling network. Mol Cell 2004;13(5):649-663.

17. Li M, Huang X, Zhu Z, Zhao Q, Wong M, Gorelik E. The terapeutic efficacy of angiostatin against weakly-and highlyimmunogenic 3LL tumors. In Vivo 2002;16(6):577-582.

18. O'Reilly MS, Holmgren L, Shing Y, Chen C, Rosenthal RA, Moses M, Lane WS, Cao Y, Sage EH, Folkman J. Angiostatin: A novel angiogenesis inhibitor that mediates the suppression of metastases by a lewis lung carcinoma. Cell 1994;79(2):315-328.

19. Konukoğlu D, Turhan SM. Molecular basis of angiogenesis mechanisms and tumor angiogenesis. Cerrahpaşa Tıp Dergisi 2005;36:42-48.

20. Cooke JP. NO and angiogenesis. Atheroscler Suppl 2003;4(4):53-60.
21. Auguet M, Lonchampt MO, Delaflotte S, Goulin-Schulz J, Chabrier PE, Braquet P. Induction of nitric oxide synthase by lipoteichoic acid from Staphylococcus aureus in vascular smooth muscle cells. FEBS Lett 1992;297:183-185.

22. Lin CH, Sheu SY, Lee HM, Ho YS, Lee WS, Ko WC, Sheu JR. Involvement of protein kinase $\mathrm{C}-\gamma$ in IL-1 $\beta$-induced cyclooxygenase2 expression in human pulmonary epithelial cells. Mol Pharmacol 2000;57:36-43.

23. Alkan ML, Beachey EH. Excretion of lipoteichoic acid by group A streptococci. Influence of penicillin on excretion and loss of ability to adhere to human oral mucosal cells. J Clin Invest 1978;61(3):671-677.

24. Ginsburg I. Role of lipoteichoic acid in infection and inflammation. Lancet Infect Dis 2002;2:171-179.

25. Morath S, Geyer A, Hartung T. Structure-function relationship of cytokine induction by lipoteichoic acid from Staphylococcus aureus. J Exp Med2001;193:393-397.

26. Opitz B, Schroder NW, Spreitzer I, Michelsen KS, Kirschning CJ, Hallatschek W. Toll-like receptor-2 mediates Treponema glycolipid and lipoteichoic acid-induced NFkappaB translocation. $J$ Biol Chem 2001;276(25):22041-22047.

27. Keller R, Fischer W, Keist R, Bassetti S. Macrophage response to bacteria: induction of marked secretory and cellular activities by lipoteichoic acids. Infect Immun 1992;60:3664-3672.

28. Yang $\mathrm{Z}$, von Ballmoos MW, Diehm N, Baumgartner I, Kalka C, Di Santo S. Call for a reference model of chronic hind limb ischemia to investigate therapeutic angiogenesis. Vascul Pharmacol2009;51(4):268-274.

29. Yavuz L, Ceylan BG, Eroğlu F. Effective and safe anesthesia methods in rats. Turkiye Klinikleri J Anest Reanim 2010;8(1):49-54.

30. Sullivan DJ. The effect of exsanguination on organ weight of rats. Toxicol Pathol1985;13(3):229-231.

31. Kim MS, Lee CS,Hur J, Cho HJ,Jun SI, Kim TY, Lee SW, Suh JW, Park KW, Lee HY, Kang 
HJ, Lee DS, Koh GY, Nakagami H, Morishita R, Park YB, Kim HS. Priming with angiopoietin-1 augments the vasculogenic potential of the peripheral blood stem cells mobilized with granulocyte colonystimulating factor through a novel Tie2/Ets1 pathway. Circulation2009;120(22):22402250 .

32. Shyu KG, Manor O, Magner $M$, Yancopoulos GD, Isner JM. Direct intramuscular injection of plasmid DNA encoding angiopoietin-1 but not angiopoietin-2 augments revascularization in the rabbit ischemic hindlimb. Circulation 1998;98:2081-2087.

33. Nykänen AI, Krebs R, Saaristo A, Turunen $\mathrm{P}$, Alitalo $\mathrm{K}$, Ylä-Herttuala $\mathrm{S}$, Koskinen PK, Lemström KB. Angiopoietin-1 protects against the development of cardiac allograft arteriosclerosis. Circulation 2003;107:1308-1314.
34. Liekens S, De Clercq E, Neyts J. Angiogenesis: Regulators and clinical applications. Biochem Pharmacol 2001;61:253-270.

35. Jakeman LB, Winer J, Bennet GL, Altar CA, Ferrera N. Binding sites for vascular endothelial growth factor are localized on endothelial cells in adult rat tissues. J Clin Invest 1992;89:244-253.

36. Sato T, El-Assal ON, Ono T, Yamanoi A, Dhar DK, Nagasue N. Sinusoidal endothelial cell proliferation and expression of angiopoietin/Tie family in regenerating rat liver. J Hepatol 2001;34:690-698.

37. Merino G, Fujino Y, Hanashiro RK. Lipoteichoic acid as an inducer of acute uveitis in the rat. IOVS 1998;39(7):12511256. 